\title{
Implementasi E-Commerce Dengan Teknik SEO dan Strategi Pemasaran 4P Untuk Meningkatkan Penjualan Produk Aksesoris Motor Pada XYZ Motoshop
}

\author{
Dedi Riandika ${ }^{1}$, Agus Umar Hamdani \\ ${ }^{1}$ Fakultas Teknologi Informasi, Sistem Informasi, Universitas Budi Luhur, Jakarta, Indonesia \\ ${ }^{2}$ Fakultas Teknologi Informasi, Sistem Informasi, Universitas Budi Luhur, Jakarta, Indonesia \\ E-mail : ${ }^{1}$ dedirian62@ gmail.com, ${ }^{2, *}$ agus.umarhamdani@budiluhur.ac.id \\ Email Penulis Korespondensi: agus.umarhamdani@budiluhur.ac.id
}

\begin{abstract}
Abstrak-XYZ Motoshop merupakan usaha perseorangan yang bergerak di bidang penjualan aksesoris dan sparepart motor yang berlokasi di Pamulang, Tangerang Selatan. Adapun permasalahan yang dialami oleh XYZ Motoshop ini antara lain : kesulitan mengetahui informasi ketersediaan produk, proses pemesanan produk yang kurang efektif dikarenakan customer harus datang langsung ke toko, pengolahan data penjualan membutuhkan waktu yang lama dikarenakan masih ditulis tangan, kesulitan mengetahui informasi pengiriman barang dikarenakan tidak ada konfirmasi penerimaan barang dan produk tidak dikenal oleh customer yang dipromosikan melalui media sosial. Untuk menyelesaikan permasalahan diatas, maka diperlukan sebuah sistem yang mampu mengelola transaksi penjualan produk dengan efektif dan efisien. Peneliti menawarkan solusi alternative guna membantu pihak manajemen untuk menyelesaikan masalah yang terjadi dengan merancang sistem $E$ commerce. Dalam penelitian ini, peneliti menggunakan pendekatan Business Model Canvas untuk menganalisa model bisnis perusahaan, analisa masalah menggunakan pendekatan Fishbone Diagram, analisa dan perancangan sistem E-Commerce menggunakan pendekatan Unified Modeling Language dan implementasi sistem E-Commerce menggunakan Content Management System, metode pencarian menggunakan teknik Search Engine Optimization dan metode pemasaran menggunakan strategi pemasaran 4P. Hasil akhir dari penelitian ini berupa website E-commerce yang dapat meningkatkan penjualan produk aksesoris motor pada XYZ Motoshop.
\end{abstract}

Kata Kunci: E-Commerce, Aksesoris Motor, Search Engine Optimation, Strategi Pemasaran 4P

\begin{abstract}
XYZ Motoshop is an individual business engaged in the sale of motorcycle accessories and spare parts, located in Pamulang, South Tangerang. The problems experienced by XYZ Motoshop include: difficulty in knowing product availability information, order process is less effective because customers must come directly to the store, sales data processing requires a long time because it is still handwritten, having difficulty to know about shipping goods because it does not have proof of receipt of goods and the customer does not recognize the product being promoted on social media. To solve the above problems, we need a system that is able to manage product sales transactions effectively and efficiently. Researchers offer alternative solutions to help management to solve problems that occur by designing e-commerce systems. In this study, researchers used the Business Model Canvas approach to analyze the company's business model, problem analysis using the Fishbone Diagram approach, analysis and design of the E-Commerce system using the Unified Modeling Language approach and implementation of the E-Commerce system using the Content Management System, the search method using techniques Search Engine Optimization and marketing methods use the 4P marketing strategy. The final results of this research are an E-Commerce Website that can increase sales of motorcycle accessories products in XYZ Motoshop.
\end{abstract}

Key Words: E-Commerce, Motorcycle Accecories, Search Engine Optimation, 4P Marketing Strategies

\section{PENDAHULUAN}

Perkembangan teknologi informasi yang semakin pesat di era globalisasi ini memberikan dampak yang signifikan di berbagai aspek kehidupan, diantaranya perdagangan, bisnis maupun organisasi. Perkembangan teknologi informasi tersebut dipicu oleh adanya kebutuhan informasi secara cepat, tepat dan terkini [1]. Menurut Haag dan Keen [2] bahwa teknologi informasi adalah seperangkat alat yang membantu pekerjaan dengan informasi dan melakukan tugas-tugas yang berhubungan dengan pemrosesan informasi. XYZ Motoshop merupakan usaha perseorangan yang bergerak di bidang penjualan aksesoris motor yang berlokasi di daerah Pamulang, Kota Tangerang Selatan.

Berdasarkan hasil pengamatan dan wawancara kepada pihak manajemen XYZ Motoshop didapatkan permasalahan bisnis sebagai berikut : proses pengolahan data penjualan produk dilakukan secara manual, yaitu customer diminta untuk datang ke toko untuk berbelanja, dan aktivitas pemasaran produk juga belum dilakukan secara efektif dan hanya mengandalkan media sosial seperti facebook, istagram, twitter, dll sehingga beberapa customer yang merasa kecewa, karena kurangnya informasi stok produk dan pencatatan laporan penjualan masih manual menggunakan tulisan tangan. Selain dua kondisi diatas, XYZ Motoshop juga sangat minim dalam penggunaan perangkat teknologi informasi untuk membantu pekerjaan sehari-hari atau bahkan untuk tujuan promosi produk.

Berdasarkan kondisi tersebut, maka dibutuhkan sebuah sistem informasi yang mampu menangani penjualan produk agar lebih optimal. E-commerce atau (Electronic Commerce) merupakan kegiatan bisnis yang dijalankan secara online dengan menggunakan jaringan internet sebagai media komunikasi atau kegiatan jual beli barang melalui jalur komunikasi digital [3]. Berbelanja online saat ini marak luas terjadi karena memberikan kemudahan bagi masyarakat mendapatkan barang yang dibutuhkan atau diinginkan dimanapun dan kapanpun asalkan semua perangkat teknologi terpenuhi [4]. Penerapan teknologi bisnis E-commerce menjadi salah satu faktor penting untuk 
membantu keberhasilan dalam menjalankan kegiatan usaha apapun baik dari segi pengelolaan data, pelayanan dan khususnya pemasaran dapat menjangkau yang tidak dapat terjangkau, serta dapat menjadi keunggulan kompetitif bagi perusahaan [5].

Beberapa studi literatur yang terkait dengan penelitian yang peneliti lakukan, antara lain : penelitian pertama membahas tentang pembangunan sistem E-Commerce untuk mendukung aktivitas pembelian dan penjualan suku cadang pada bengkel Tiga Putra Motor Garut [6], penelitian kedua membahas tentang perancangan sistem informasi penjualan aksesoris vespa berbasis web pada CV. A.S. Hikmat Motor Bekasi [7], penelitian ketiga membahas tentang perancangan sistem informasi penjualan pada Toko Al-Idan Variasi Motor Kelurahan Karang Baru, Mataram [8], penelitian keempat, membahas implementasi Search Engine Optimization (SEO) On Page pada Web UMKM Batik dan Handicraft [9], dan penelitian terakhir membahas implementasi Search Engine Optimization (SEO) Pada Situs Rental-Mobil-Malang.com menggunakan Metode Off Page Seo [10].

Adapun perbedaan antara penelitian sebelumnya dengan penelitian yang peneliti lakukan adalah pada penelitian sebelumnya hanya membahas analisa dan perancangan E-Commerce hingga implementasi Search Engine Optimization (SEO), sedangkan pada penelitian yang penulis lakukan terdapat penambahan fitur pencarian dengan Search Engine Optimization (SEO) dan strategi pemasaran.

Berdasarkan latar belakang diatas, maka peneliti melakukan kajian penelitian untuk membangun sistem ECommerce guna membantu XYZ Motoshop untuk meningkatkan penjualan dan pemasaran produk aksesoris motor. Rumusan masalah yang harus dijawab dalam penelitian ini adalah bagaimana model sistem E-Commerce yang dapat meningkatkan penjualan dan pemasaran pada XYZ Motoshop?

\section{METODOLOGI PENELITIAN}

Penelitian ini merupakan penelitian terapan (Applied Research), dimana peneliti melakukan studi mendalam mengenai masalah bisnis yang terjadi, kemudian memberikan solusi bisnis berupa penggunaan teknologi ECommerce guna mendukung penjualan produk pada XYZ Motoshop.

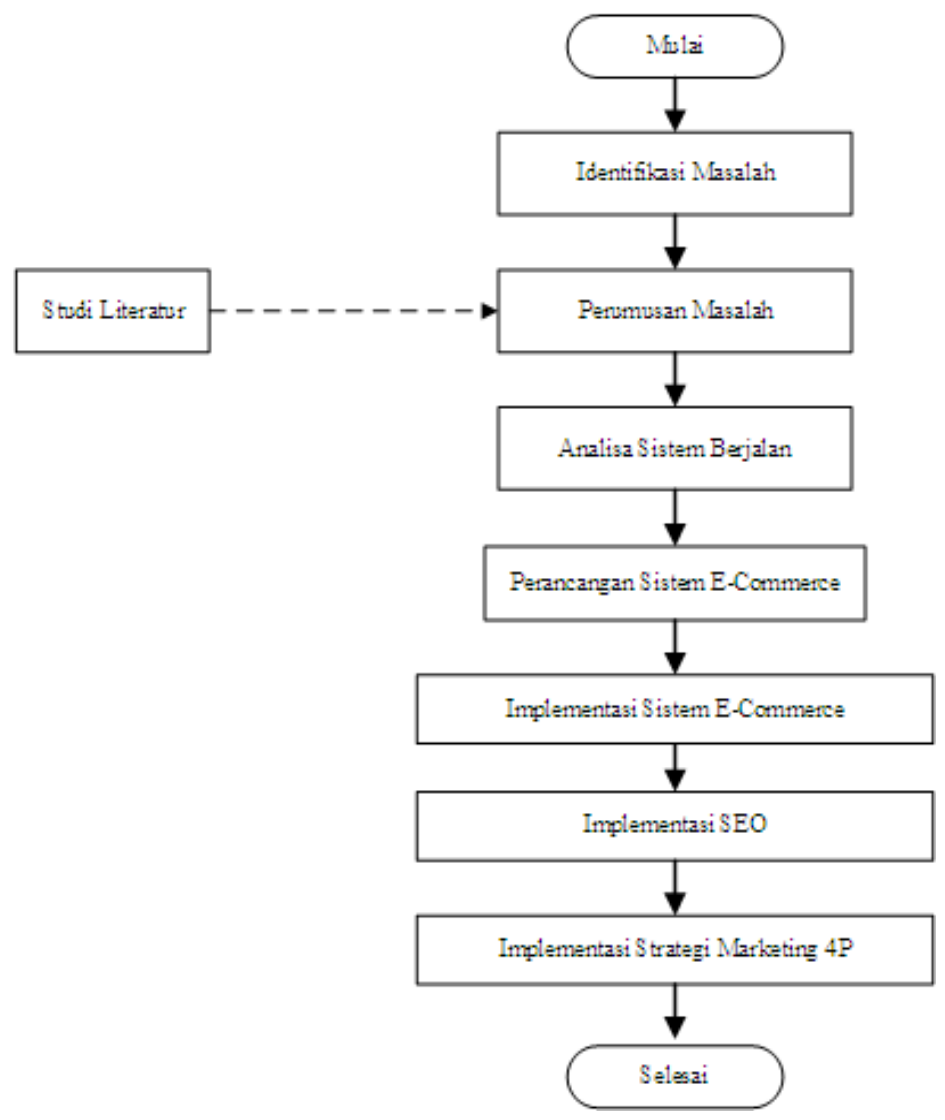

Gambar 1. Langkah-Langkah Penelitian

Berdasarkan gambar 1 diatas, maka berikut ini penjelasan mengenai tahapan-tahapan penelitian :

Tahap mulai : peneliti melakukan observasi terhadap kondisi bisnis dan kondisi penggunaan teknologi informasi yng ada di instansi saat ini, Tahap identifikasi masalah : peneliti melakukan analisis masalah bisnis yang terjadi di instansi dan menggambarkan masalah tersebut menggunakan pendekatan model Fishbone Diagram. Fishbone Diagram digunakan untuk mengetahui akibat dari suatu masalah, dicari beberapa kemungkinan penyebabnya, kemudian selanjutna diambil tindakan [11]. Adapun analisis Fishbone Diagram yang digunakan adalah konsep 7P 
(Process, Place, Price, Product, Physical Evidence, Productivity and Quality). Tahapan ketiga studi literature, peneliti melakukan review studi literatur terhadap topik penelitian yang sesuai, Tahap keempat, peneliti membuat rumusan masalah yang harus dijawab pada penelitian ini, Tahap kelima analisis sistem berjalan : peneliti melakukan analisis model bisnis menggunakan Business Model Canvas (BMC), menurut Frans Royan [12], Business Model Canvas merupakan kerangka kerja (frame work) untuk memetakan bisnis kita agar kinerjanya lebih optimal. Kemudian membuat analisis model proses bisnis menggunakan model Activity Diagram, dan membuat tabel identifikasi kebutuhan sistem usulan, Tahap keenam perancangan model fungsional, adapun pendekatan yang digunakan adalah Unified Modeling Language (UML), adapun diagram yang digunakan adalah Activity Diagram, Use Case Diagram dan Class Diagram, Tahap ketujuh, penulis membangun website ECommerce menggunakan Content Management System Wordpress, Content Management System adalah software yang dibangun khusus untuk membuat toko di dunia maya atau yang sering disebut E-Commerce [13]. Tahap kedelapan implementasi teknik Search Engine Optimation (SEO), SEO adalah serangkaian proses yang dilakukan secara sistematis yang bertujuan untuk meningkatkan volume dan kualitas trafik kunjungan melalui mesin pencari dengan memanfaatkan mekanisme kerja atau algoritma mesin pencari tersebut [14]. Peneliti menggunakan pendekatan White-Hat SEO dengan teknik Onpage, Tahap kesembilan implementasi strategi pemasaran 4P. Strateggi 4P atau marketing mix adalah perangkat alat pemasaran taktis yang dapat dikendalikan, produk (product), harga (price), distribusi (place) da promosi (promotion) yang dipadukan oleh perusahaan untuk menghasilkan respon yang diinginkan dalam pasar sasaran [15]. Peneliti mengimplementasikan strategi pemasaran 4P guna menunjang pemasaran dan promosi produk aksesoris motor yang ada pada XYZ Motoshop, Tahap selesai, peneliti melakukan evaluasi dan menarik kesimpulan dari hasil analisa, perancangan dan implementasi sistem E-Commerce pada XYZ Motoshop.

\section{HASIL DAN PEMBAHASAN}

\subsection{Analisis Model Bisnis menggunakan pendekatan Business Model Canvas (BMC)}

Sebelum melakukan identifikasi kebutuhan sistem E-Commerce, peneliti terlebih dulu melakukan analisis model bisnis perusahaan menggunakan pendekatan Business Model Canvas (BMC). Berikut ini adalah urutan analisis dalam BMC, diawali dengan analisis value proposition (nilai bisnis yang ditawarkan), key activities (aktivitas bisnis yang menjadi kunci), key resource (sumber daya kunci), key patner (mitra kunci), customer segmentation (segmentasi pelanggan), customer relationship (metode/cara berhubungan dengan pelanggan), channel (media komunikasi), cost structure (struktur biaya yang dikeluarkan karena bisnis tersebut) dan revenue stream (aliran pendapatan yang diterima). Adapun hasil analisa model bisnis pada XYZ Motoshop dijelaskan dalam gambar 2.

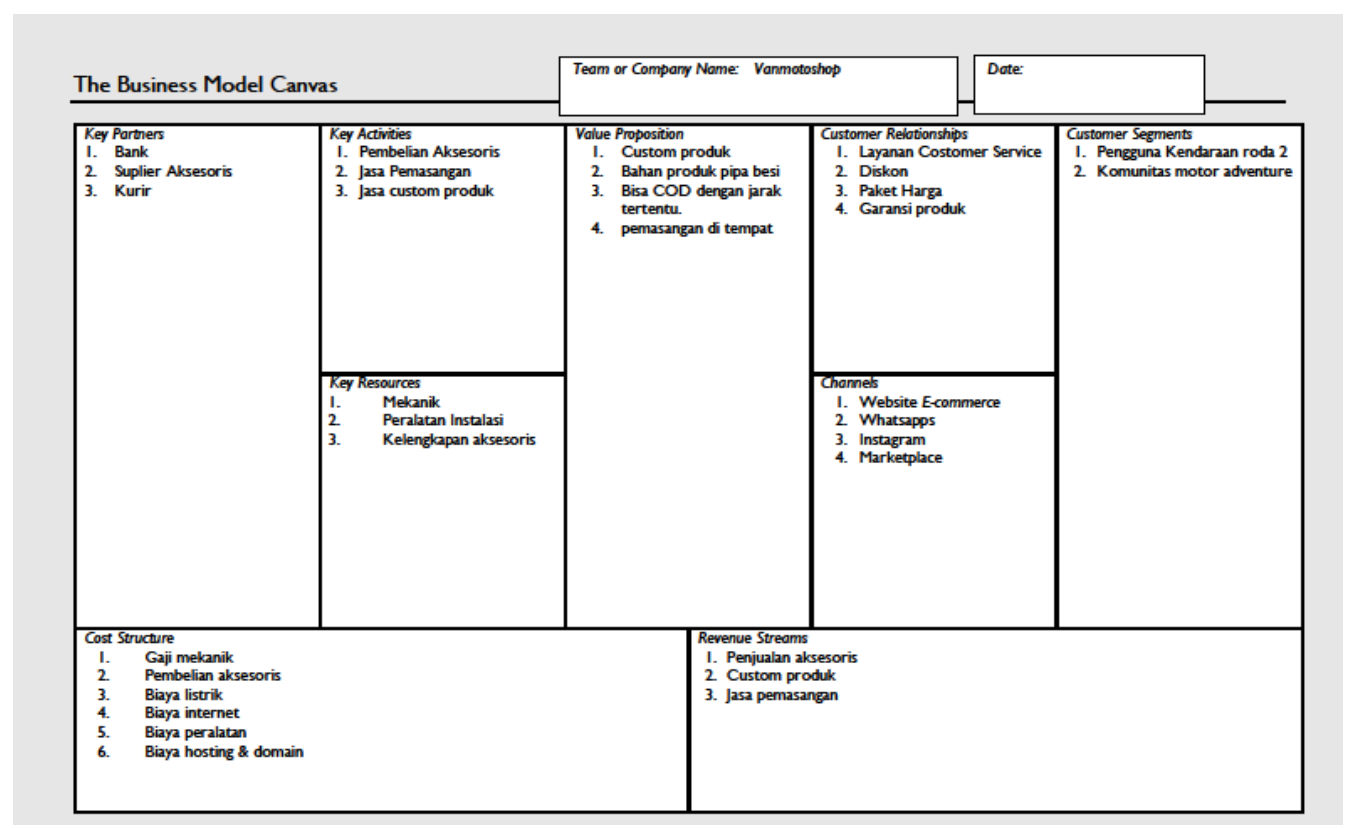

Gambar 2. Hasil Analisis Business Model Canvas

\subsection{Analisis Masalah Menggunakan Pendekatan Fishbone Diagram}

Pada tahapan ini, peneliti melakukan identifikasi masalah bisnis yang terjadi di XYZ Motoshop dengan menggunakan pendekatan Fishbone Diagram dengan teknik 8P (People, Process, Product, Promotion, Price, Place, Physical Evidence dan Productivity and Quality. Berikut ini adalah hasil analisa masalah bisnis yang terjadi di XYZ Motoshop yang dijelaskan pada gambar 3. 


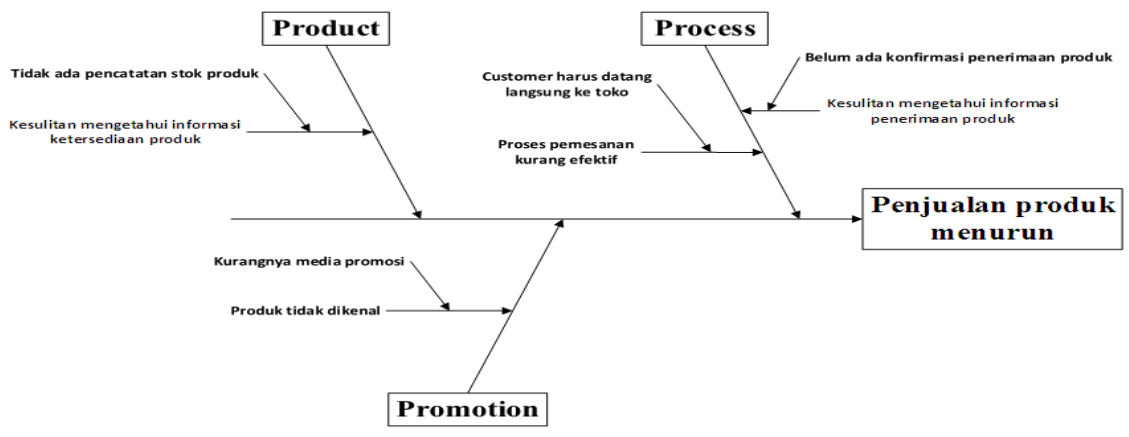

Gambar 3. Analisis Masalah Dengan Fishbone Diagram

Berdasarkan hasil analisis masalah diatas, maka peneliti memberikan solusi yang ditawarkan / identifikasi kebutuhan sistem yang selengkaptnya dapat dilihat pada tabel 1.

Tabel 1. Solusi / Identifikasi Kebutuhan Sistem

\begin{tabular}{|c|c|c|c|}
\hline $\begin{array}{l}\text { Kategori } \\
\text { Masalah }\end{array}$ & $\begin{array}{c}\text { Pernyataan Masalah } \\
\text { (Problem Statements) }\end{array}$ & $\begin{array}{c}\text { Penyebab } \\
(\text { Causes })\end{array}$ & $\begin{array}{c}\text { Solusi / Identifikasi } \\
\text { Kebutuhan Sistem } \\
\end{array}$ \\
\hline $\begin{array}{l}\text { Product } \\
\text { (Produk) }\end{array}$ & $\begin{array}{l}\text { - Kesulitan mengetahui } \\
\text { informasi ketersediaan } \\
\text { produk }\end{array}$ & $\begin{array}{l}\text { - Tidak ada pencatatan stok } \\
\text { produk }\end{array}$ & $\begin{array}{l}\text { - Sistem E-Commerce harus } \\
\text { bisa menyediakan informasi } \\
\text { ketersediaan stok produk. }\end{array}$ \\
\hline $\begin{array}{l}\text { Process } \\
\text { (Proses) }\end{array}$ & $\begin{array}{l}\text { - Proses pemesanan produk } \\
\text { kurang efektif. }\end{array}$ & $\begin{array}{l}\text { - Customer harus datang } \\
\text { langsung ke toko. }\end{array}$ & $\begin{array}{l}\text { Sistem E-Commerce harus } \\
\text { menyediakan fitur untuk } \\
\text { pemesanan secara online. }\end{array}$ \\
\hline $\begin{array}{l}\text { Process } \\
\text { (Proses) }\end{array}$ & $\begin{array}{l}\text { - Kesulitan mengetahui } \\
\text { informasi penerimaan } \\
\text { produk. }\end{array}$ & $\begin{array}{l}\text { - Belum ada konfirmasi } \\
\text { penerimaan produk. }\end{array}$ & $\begin{array}{l}\text { - Sistem E-Commerce harus } \\
\text { menyediakan fitur } \\
\text { konfirmasi penerimaan } \\
\text { produk. }\end{array}$ \\
\hline $\begin{array}{l}\text { Promotion } \\
\text { (Promosi) }\end{array}$ & $\begin{array}{l}\text { - Produk tidak dikenal oleh } \\
\text { customer. }\end{array}$ & - Kurangnya media promosi. & $\begin{array}{l}\text { - Sistem E-Commerce harus } \\
\text { menyediakan fitur untuk } \\
\text { promosi produk. }\end{array}$ \\
\hline
\end{tabular}

\subsection{Analisa Proses Bisnis menggunakan Activity Diagram}

Activity diagram meruapakan gambaran sebuah alur dari aktifitas yang dilakukan oleh proses bisnis. Berikut ini adalah proses bisnis usulan yang digambarkan menggunakan activity diagram. Customer yang hendak ingin melakukan pemesanan harus login terlebih dahulu. Jika tidak bisa bisa, maka customer harus registrasi yang tersedia di sistem. Customer memilih produk yang ingin di beli an memasukkannya ke keranjang belanja. Lalu customer mengatur jumlah produk yang ingin di pesan. Jika sudah selesai customer memilih halaman checkout untuk melengkapi data pemesanan. Lalu customer mengisi data checkout dan sistem akan menampilkan total biaya pesanan yang harus dibayarkan. Lalu customer setuju membuat pesanan dan sistem otomatis menyimpan data pesanan. Setelah itu customer akan mendapatkan notifikasi email yang berupa rincian pesanan dan total yang harus dibayarkan. Aktivitas pemesanan tersebut dapat dilihat pada gambar 4 .

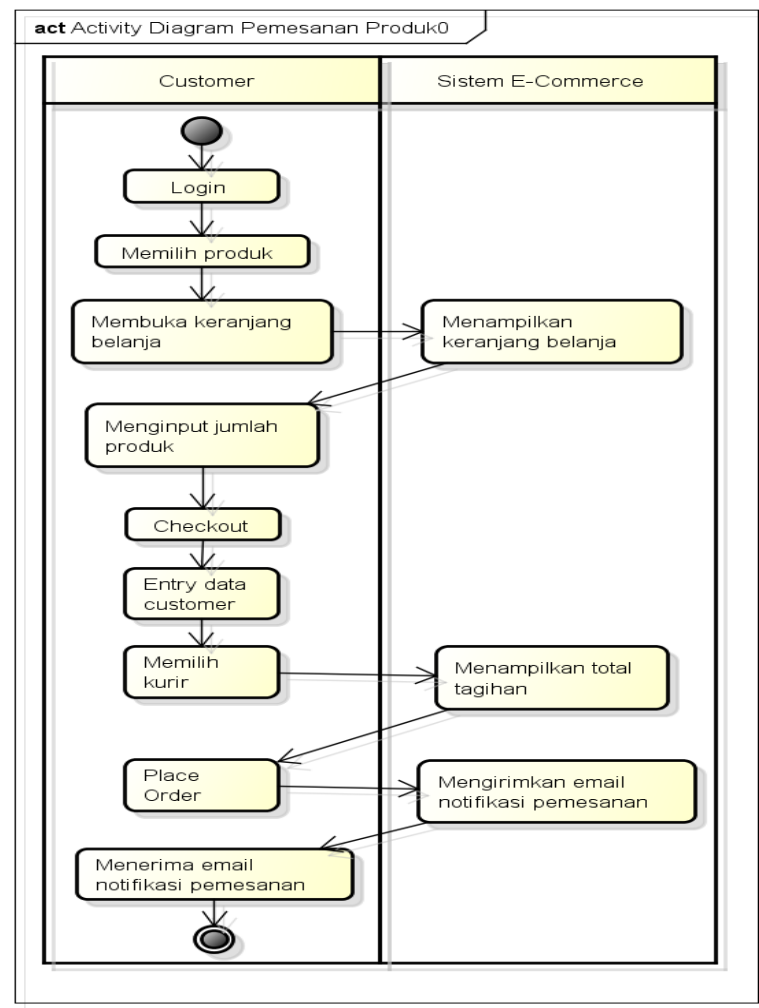

Gambar 4. Activity Diagram Pemesanan Produk 
Customer melakukan pembayaran, kemudian customer melakukan konfirmasi pembayaran dengan mengentry data detail pembayaran, serta mengupload bukti pembayaran ke aplikasi E-Commerce. Lalu sistem akan mengirim email konfirmasi pembayaran ke admin. Admin mengecek konfirmasi pembayaran. Jika tidak sesuai, admin akan mengirim email bukti penerimaan pembayaran kepada customer. Adapun proses pembayaran dapat dilihat pada gambar 5 .

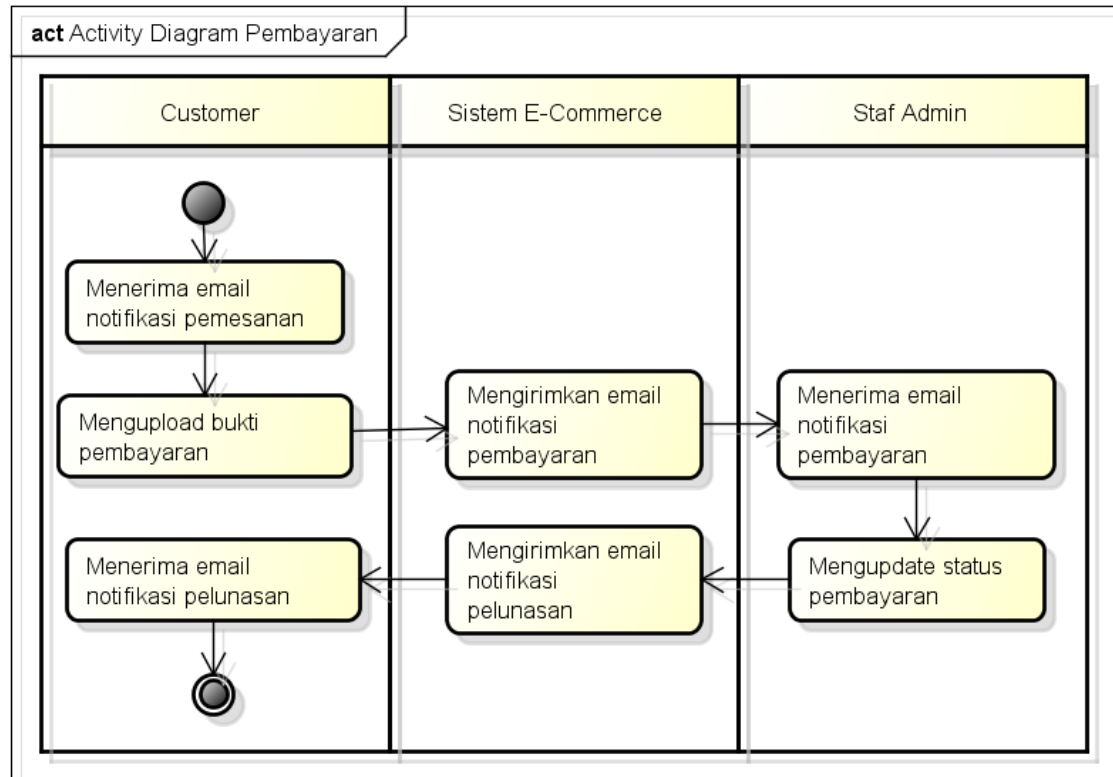

Gambar 5. Activity Diagram Pembayaran

Kemudian admin akan menginput resi pengiriman barang yang diterima dari kurir, kemudian sistem akan melakukan notifikasi pengiriman barang kepada customer. Selengkapnya dapat dilihat pada gambar 6 .

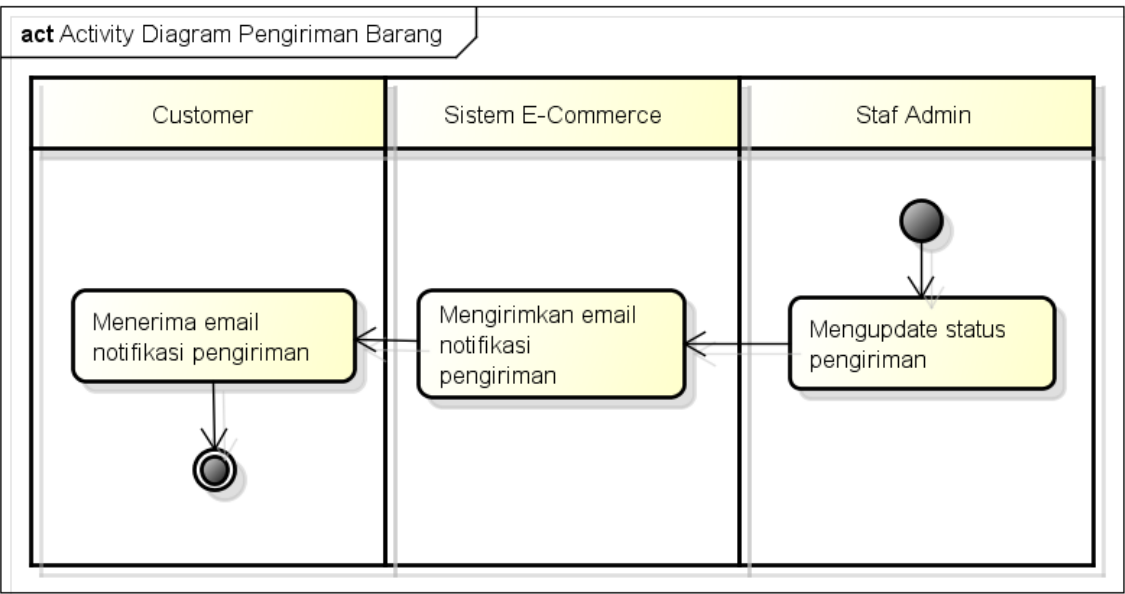

Gambar 6. Activity Diagram Pengiriman Produk

\subsection{Pemodelan Domain Data Model Menggunakan Class Diagram}

Class Diagram merupakan gambaran dari domain dari masalah dan menjadi inti dari pengembangan sebuah sistem. Adapun domain data model yang terbentuk untuk pengembangan sistem E-Commerce pada XYZ Motoshop mengikuti model yang terdapat dalam CMS Wordpress, yang terdiri atas : kelas users dan usermeta, kelas posts dan postmeta digunakan untuk merekam data posting, kelas order_items dan order_itemsmeta digunakan untuk merekam data pemesanan dan detail pesanan, kelas product digunakan untuk merekam data produk, kelas termmeta, terms dan term_taxonomy digunakan merekam data tema, kelas digunakan untuk merekam data tema, term relationship digunakan untuk merekam data relasi tema, kelas comments dan commentmeta digunakan untuk merekam data komentar. Selengkapnya, model domain data untuk sistem ECommerce pada XYZ Motoshop dijelaskan pada gambar 7. 
JURNAL MEDIA INFORMATIKA BUDIDARMA

Volume 4, Nomor 3, Juli 2020, Page 785-796

ISSN 2614-5278 (media cetak), ISSN 2548-8368 (media online)

Available Online at https://ejurnal.stmik-budidarma.ac.id/index.php/mib DOI $10.30865 / \mathrm{mib} . v 4 \mathrm{i} 3.2242$

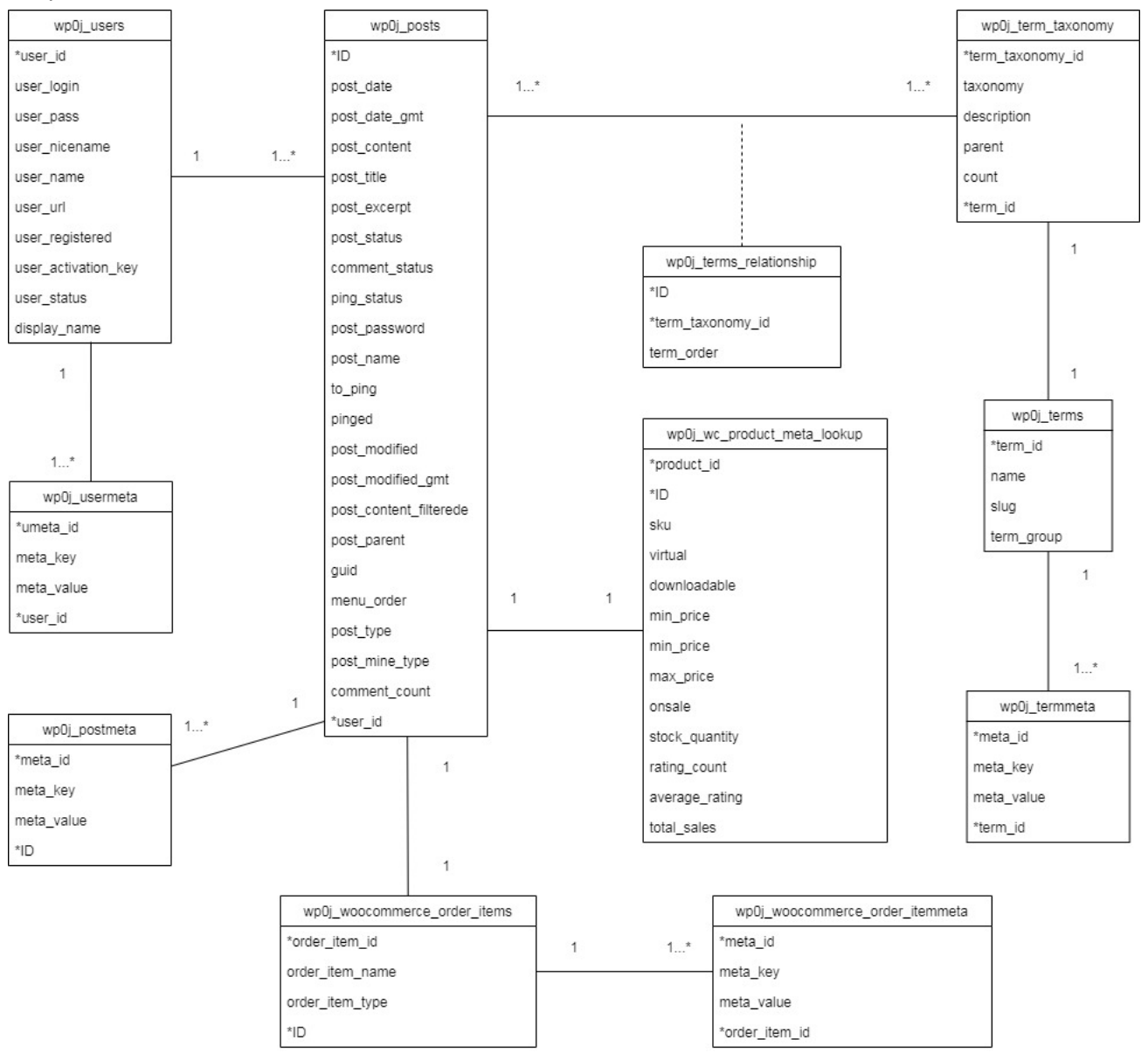

Gambar 7. Model Domain Data Menggunakan Class Diagram

\subsection{Pemodelan Fungsional Sistem E-Commerce Menggunakan Use Case Diagram}

Use Case Diagram untuk mengambarkan interaksi antar actor dengan sistem E-Commerce. Berikut ini adalah model fungsionalitas sistem E-Commerce :

a. Use Case Diagram Master

Use case diagram master terdiri dari : use case entry produk digunakan untuk merekam data produk yang dijual, use case entry kategori digunakan untuk merekam data kategori produk, use case entry data kurir digunakan untuk merekam data kurir, use case entry diskon digunakan untuk merekam data diskon dan use case registrasi digunakan untuk merekam data registrasi customer. Adapun actor yang terlibat dalam use case master ini adalah admin dan customer. Selengkapnya use case diagram master dapat dilihat pada gambar 8 .

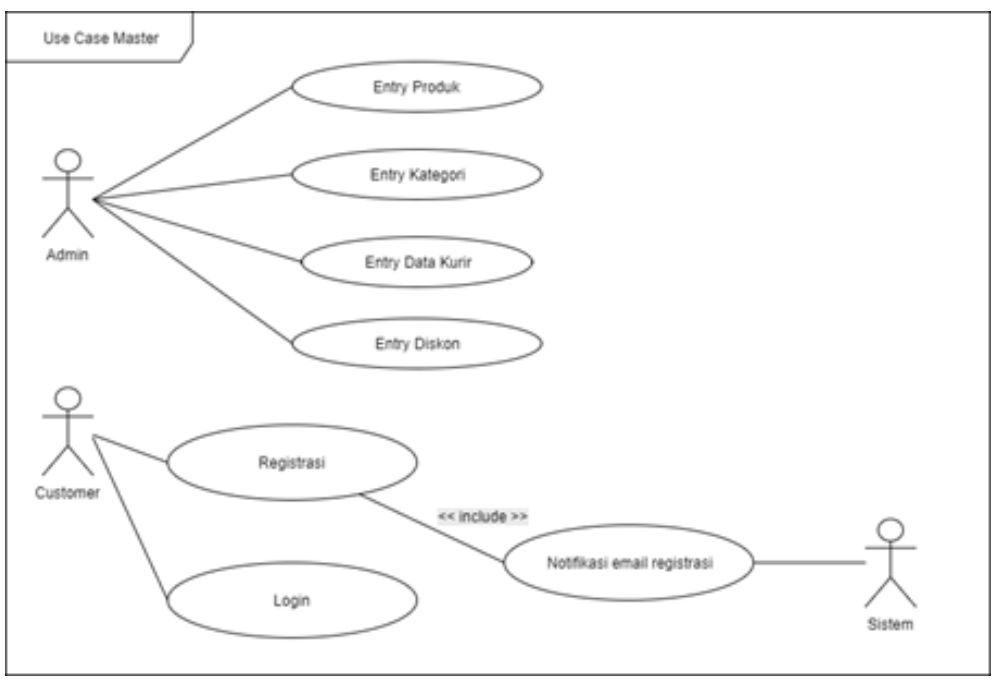

Gambar 8. Use Case Diagram Master 
JURNAL MEDIA INFORMATIKA BUDIDARMA

Volume 4, Nomor 3, Juli 2020, Page 785-796

ISSN 2614-5278 (media cetak), ISSN 2548-8368 (media online)

Available Online at https://ejurnal.stmik-budidarma.ac.id/index.php/mib

DOI $10.30865 /$ mib.v4i3.2242

b. Use Case Diagram Transaksi

Use case diagram transaksi yang dijalankan oleh customer terdiri dari : use case entry pemesanan digunakan untuk merekam data pemesanan produk, use case upload bukti pembayaran digunakan untuk mengupload bukti pembayaran dan use case entry penerimaan produk digunakan untuk merekam data penerimaann produk.sedangkan aktivitas yang dilakukan oleh admin, antara lain : use case entry resi pengiriman digunakan untuk merekam data pengiriman produk dan use case ubah status pengiriman digunakan untuk merekam informasi perubahan status pengiriman produk.

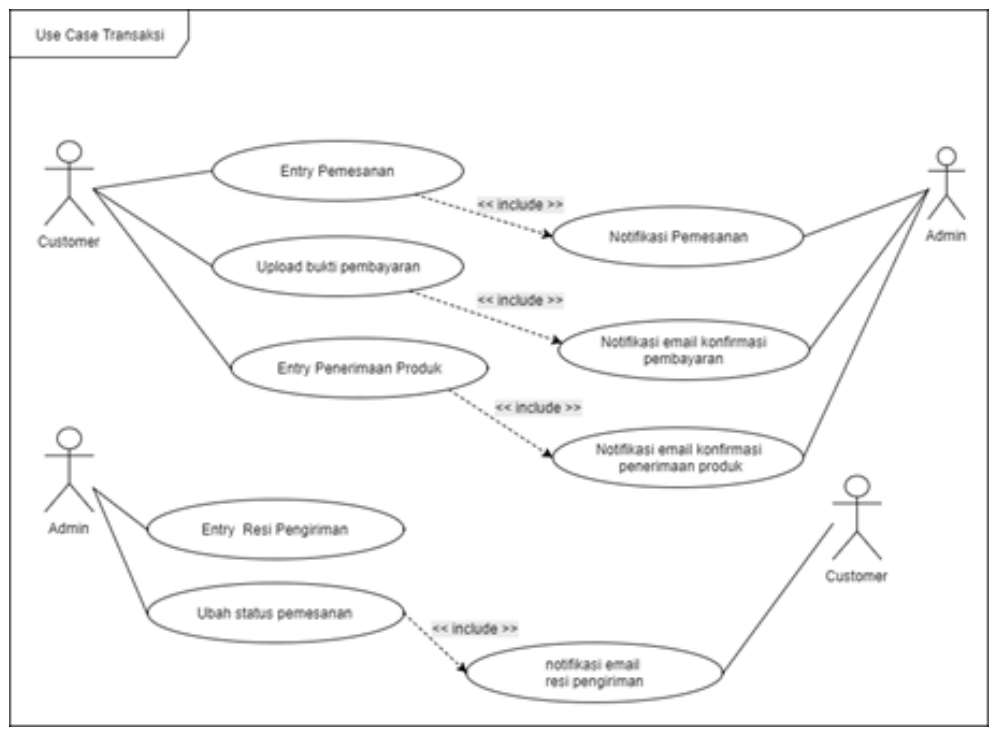

Gambar 9. Use Case Doagram Transaksi

c. Use Case Diagram Laporan

Use case diagram laporan yang dijalankan oleh admin dan pemilik took terdiri dari : use case laporan penjualan digunakan untuk menampilkan informasi penjualan produk, use case laporan pembayaran digunakan untuk menampilkan informasi pembayaran, use case laporan pengiriman digunakan untuk menampilkan informasi pengiriman produk, use case laporan stok produk digunakan untuk menampilkan informasi stok produk, use case laporan produk terlaris digunakan untuk menampilkan informasi produk terlaris dan use case laporan rekapitulasi pendapatan digunakan untuk menampilkan informasi pendapatan toko. Selengkapnya use case laporan tersebut dapat dilihat pada gambar 10.

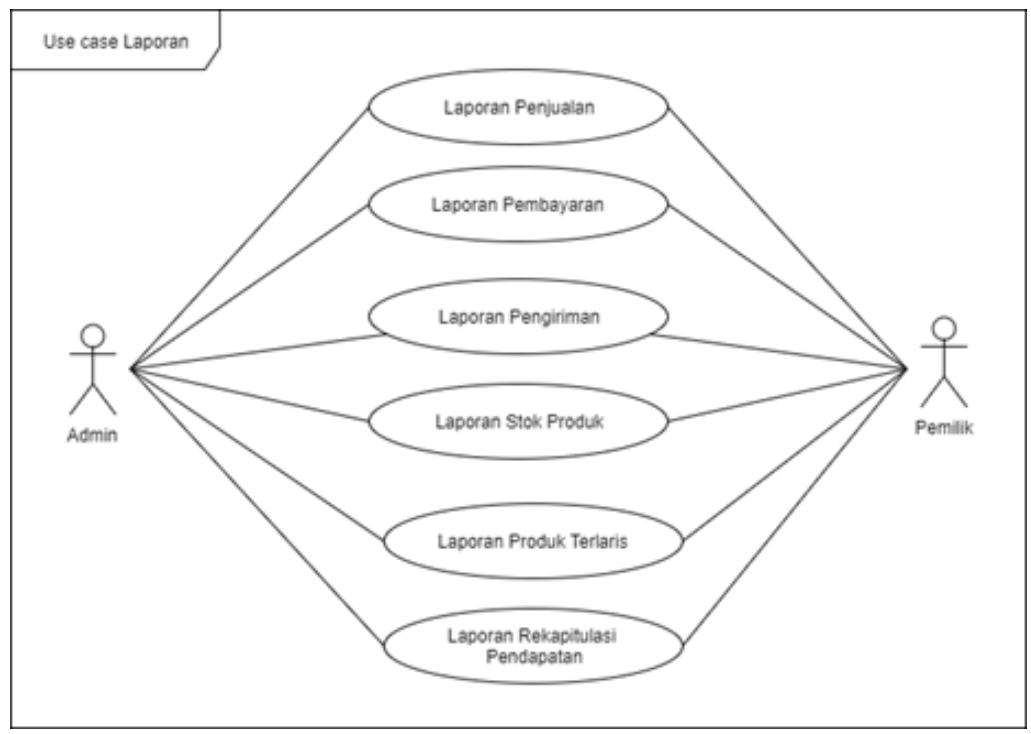

Gambar 10. Use Case Laporan

3.6 Model Interaksi Pengguna dan Sistem Menggunakan Interaction Flow Modeling Languange (IFML)

Interaction Flow Modeling Language adalah bahasa pemodelan untuk front-end pada perangkat lunak yang terinspirasi dari webml yang digunakan untuk mengekspresikan konten, interaksi penguna, dan mengatur perilaku pada Front-End dari sebuah perangkat lunak. Berikut ini beberapa model IFML ada yang ada pada XYZ Motoshop: 
JURNAL MEDIA INFORMATIKA BUDIDARMA

Volume 4, Nomor 3, Juli 2020, Page 785-796

ISSN 2614-5278 (media cetak), ISSN 2548-8368 (media online)

Available Online at https://ejurnal.stmik-budidarma.ac.id/index.php/mib

DOI 10.30865/mib.v4i3.2242

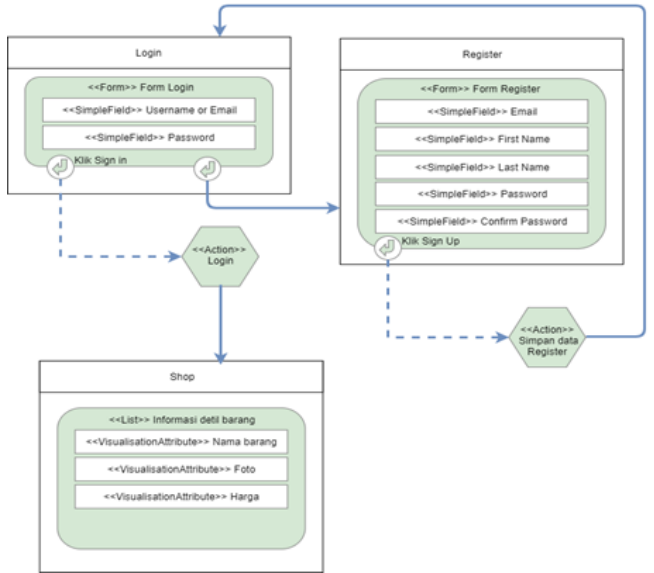

Gambar 11. IFML Registrasi Customer

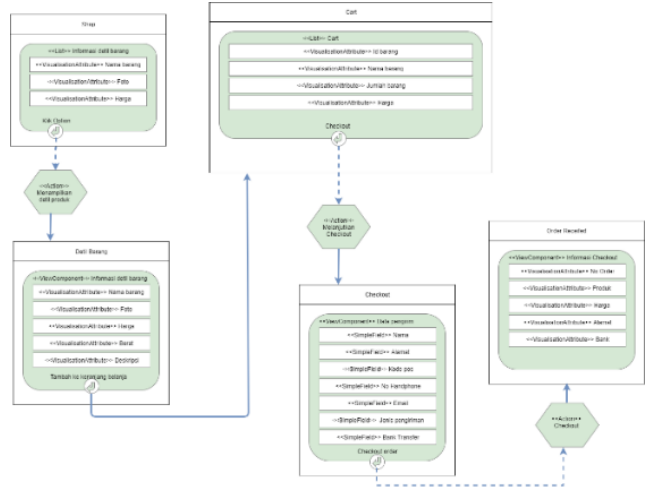

Gambar 12. IFML Pemesanan Produk

3.7 Model Perilaku Sistem Menggunakan System Sequance Diagram (SSD)

Berikut adalah System Sequence diagram (SSD) Entry Pemesanan yang dijelaskan pada gambar 9 :

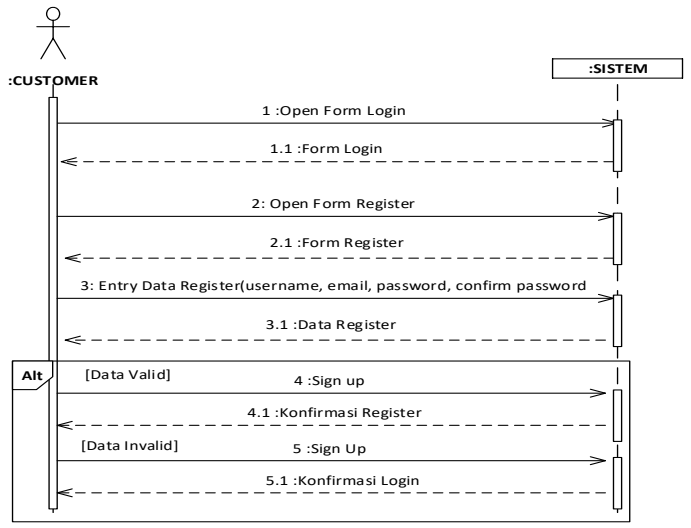

Gambar 13. System Sequence Diagram Registrasi Customer

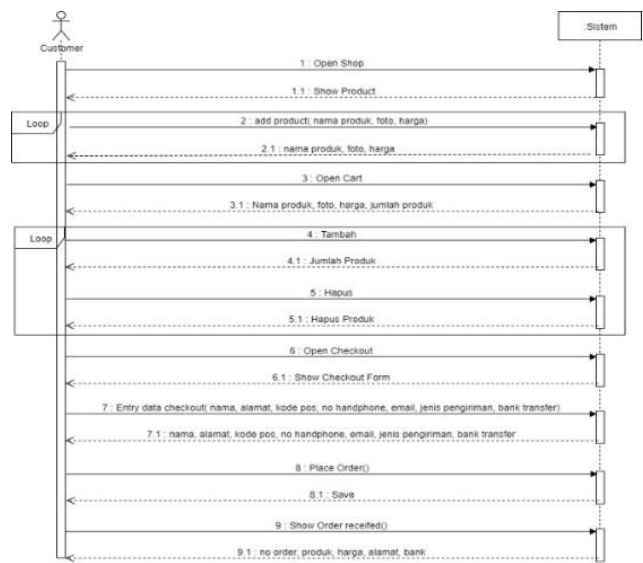

Gambar 14. System Sequence Diagram Pemesanan Produk

\subsection{User Interface untuk sistem E-Commerce pada XYZ Motoshop}

Berikut ini adalah tampilan halaman website E-Commerce dengan alamat website di : http://vanmotoshop.com
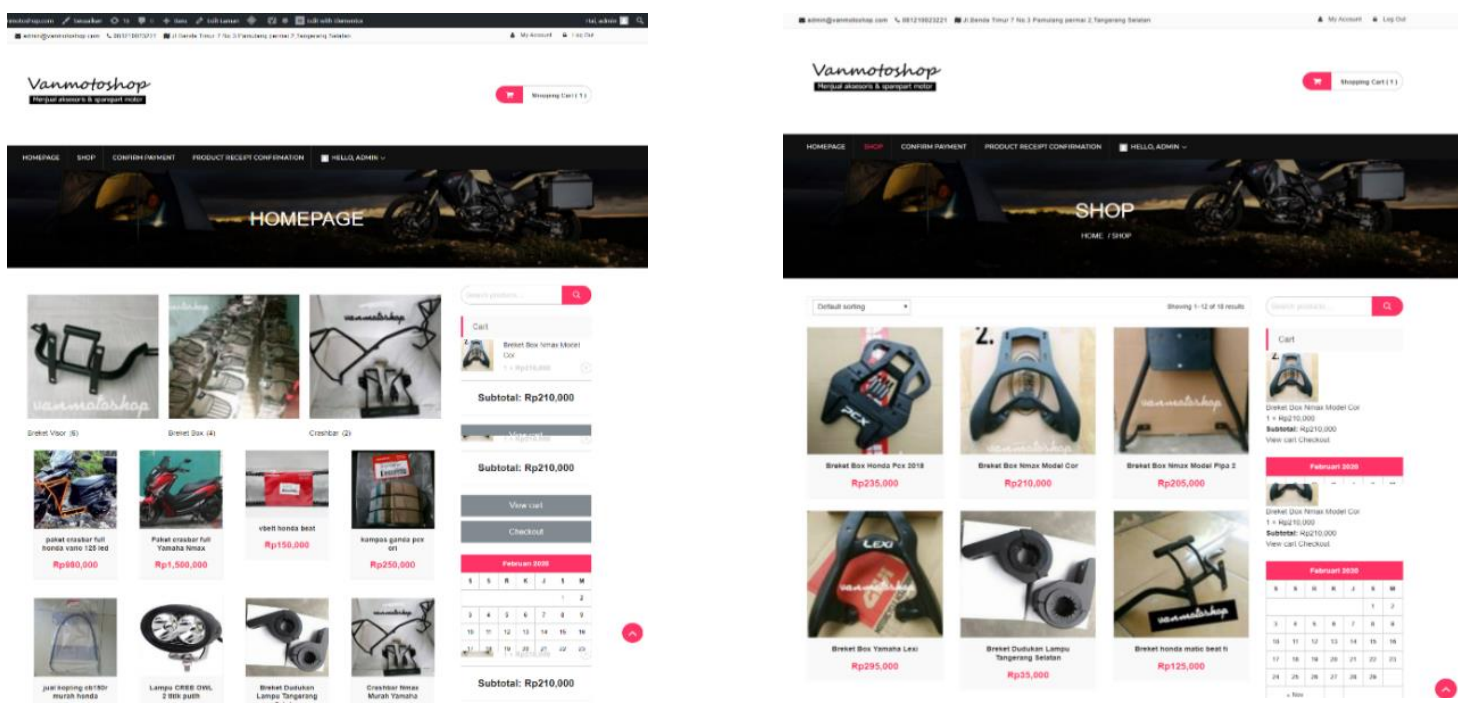

Gambar 15. Halaman Depan Website E-Commerce

Gambar 16. Halaman Toko Online 
ISSN 2614-5278 (media cetak), ISSN 2548-8368 (media online)

Available Online at https://ejurnal.stmik-budidarma.ac.id/index.php/mib DOI $10.30865 /$ mib.v4i3.2242
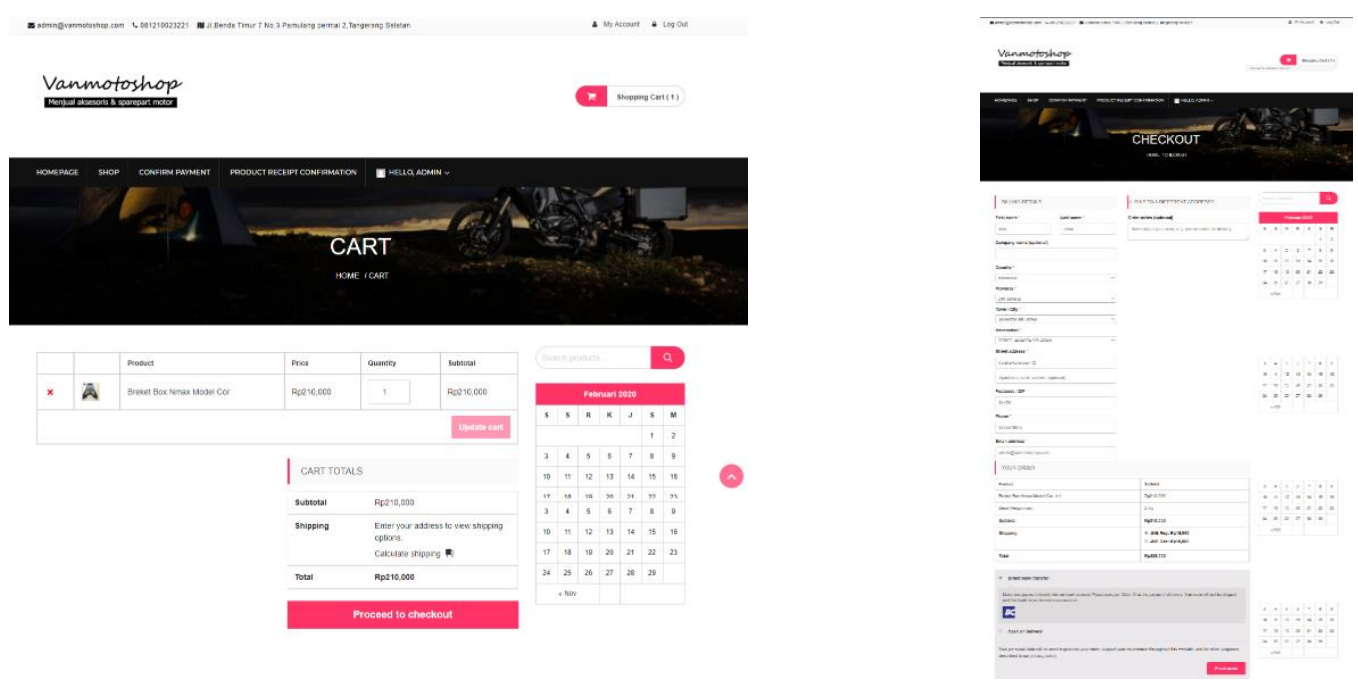

Gambar 17. Halaman Cart

Gambar 18. Halaman Checkout

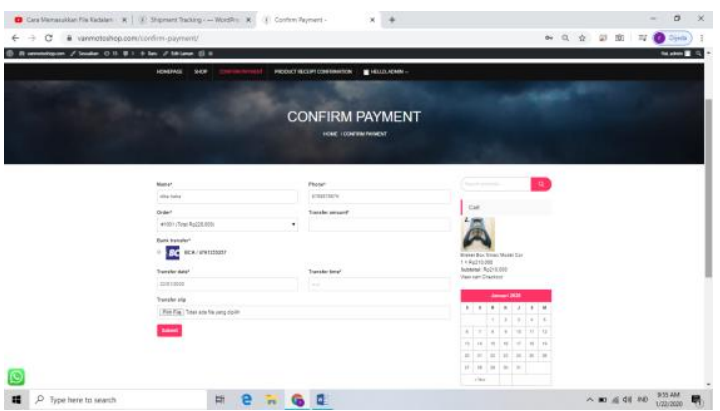

Gambar 19. Halaman Konfirmasi Pembayaran

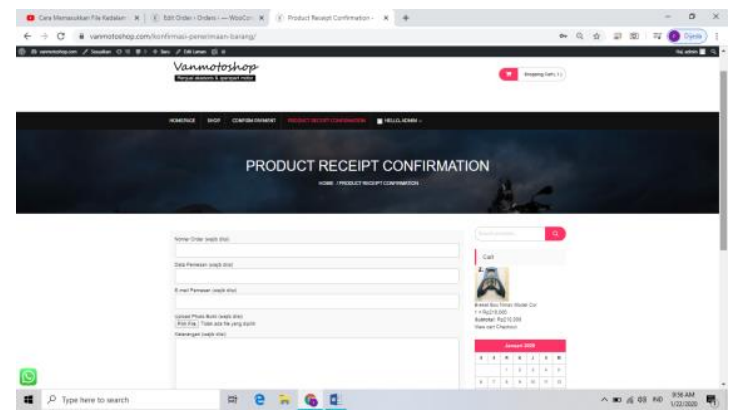

Gambar 21. Halaman Konfirmasi Penerimaan Produk

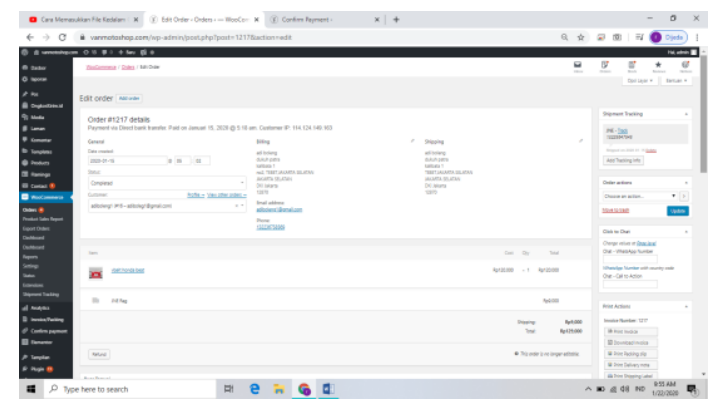

Gambar 20. Halaman Konfirmasi Pengiriman Produk

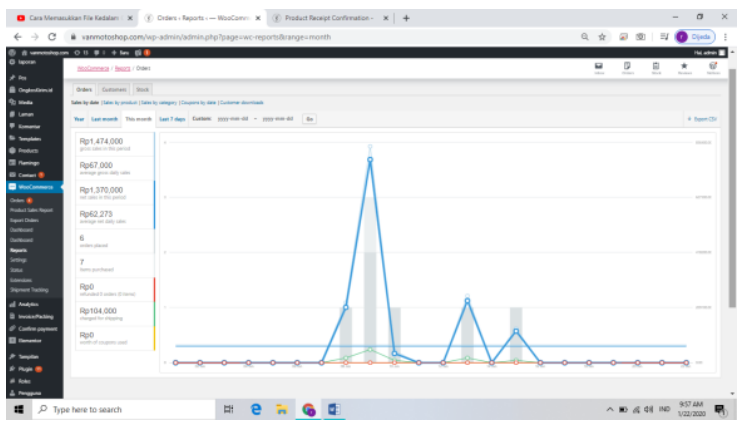

Gambar 22. Halaman Untuk Menampilkan Laporan Rekapitulasi Penjualan Produk

\subsection{Implementasi Search Engine Optimation (SEO)}

Implementasi dari penerapan Search Engine Optimation (SEO) dengan pendekatan White-Hat SEO melalui teknik Onpage SEO menggunakan Plugin Yoast SEO yang terdapat dalam CMS Wordpress. Peneliti terlebih dahulu melakukan instalasi Plugin Yoast SEO dan melakukan konfigurasi setting Yoast SEO di menu produk. Kemudian memilih Google Verification Code untuk menyambungkan ke Google Search Console. Setelah itu, baru menambahkan link pencarian dan domain di Google Search Console dan setelah itu mengupload file verifikasi. Kemudian menyalin code yang tersedia ke template yang digunakan dan paste-kan ke menu Verifikasi Google Search Console di Plugin Yoast SEO dan memilih menu Verify. Kemudian klik menu Sitemaps dan memasukkan bagian akhir dari URL Sitemaps ke dalam New Sitemaps dan kemudian Submit. 
ISSN 2614-5278 (media cetak), ISSN 2548-8368 (media online)

Available Online at https://ejurnal.stmik-budidarma.ac.id/index.php/mib

DOI 10.30865/mib.v4i3.2242

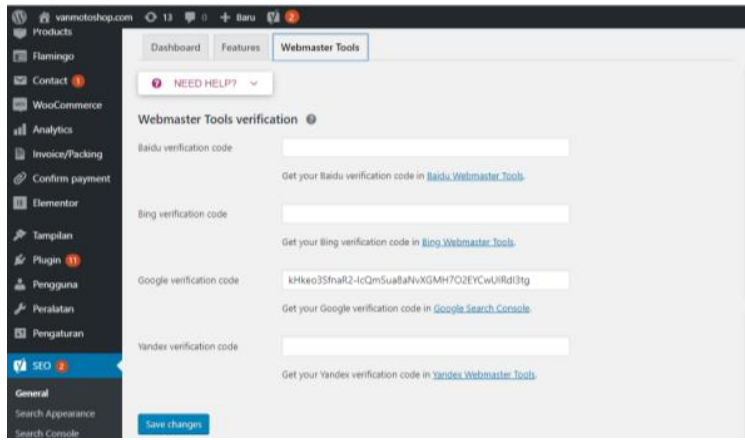

Gambar 23. Instalasi Plugin Yoast SEO

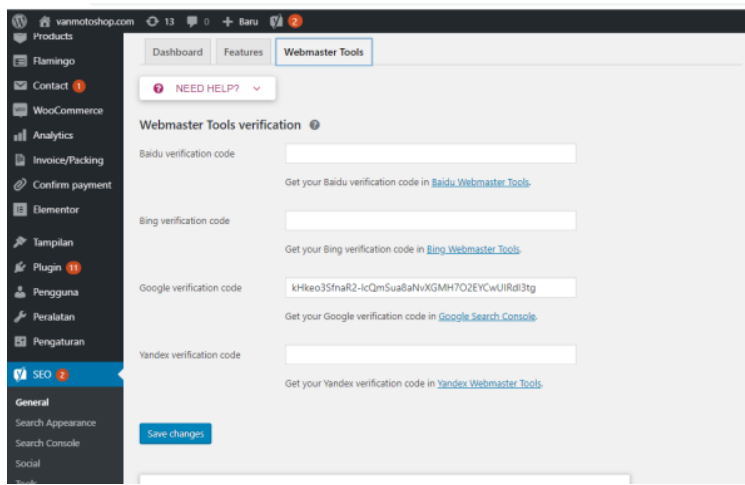

Gambar 25. Memilih Google Verification Code

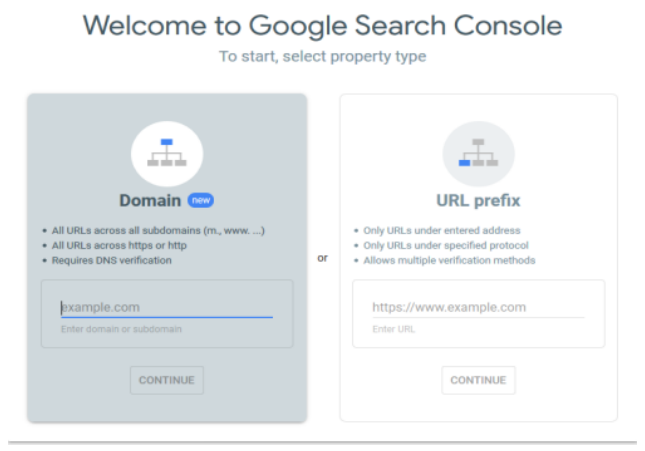

Gambar 24. Memilih Google Search Console

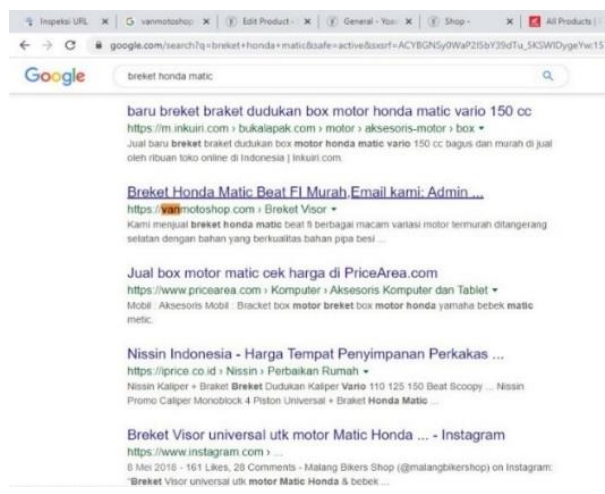

Gambar 26. Hasil Pencarian Di Google Search

\subsection{Implementasi Strategi Pemasaran / Marketing 4P}

Strategi Pemasaran / Marketing yang diterapkan dalam sistem E-Commerce Pada XYZ Motoshop dalam rangka meningkatkan penjualan produk aksesoris motor menggunakan pendekatan strategi marketing 4P (Product, Price, Place dan Promotion). Dari keempat komponen tersebut, hanya komponen Product, Price dan Promotion yang digunakan dalam penelitian ini. Berikut ini adalah hasil strategi pemasaran yang diusulkan :

Tabel 2. Implementasi Strategi Pemasaran 4P

$\begin{gathered}\text { Komponen } \\ \text { Strategi } \\ \text { Pemasaran 4P }\end{gathered}$
$\begin{aligned} & \text { Price dan } \\ & \text { Product } \\ & \text { (strategi harga }\end{aligned}$
$\begin{aligned} & \text { kemberian diskon / potongan } \\ & \text { kan produk) }\end{aligned}$




\begin{tabular}{ccc}
\hline Komponen & Strategi yang dilakukan & Implementasi Strategi Pemasaran / Marketing 4P \\
Strategi & \\
Pemasaran 4P &
\end{tabular}

\section{Promotion} (Strategi promosi)
- Selain dilakukan melalui website E-Commerce, promosi juga dilakukan melalui media social seperti facebook dan istagram, juga melalui marketplace seperti bukalapak, shopee dan tokopedia.

- Membuat postingan promosi produk dilakukan pada media sosial pada jam-jam tertentu :

- Pukul 11.00 - 12.00 adalah waktu orang-orang istirahat dari kesibukan mereka.

- Pukul 17.00 s.d 22.00, malam hari adalah waktu paling leluasa untuk seseorang menggunakan gadget mereka lebih sering.

- Tidak cantumkan harga pada postingan postingan, hal ini diharapkan agar customer langsung mengakses website toko online.

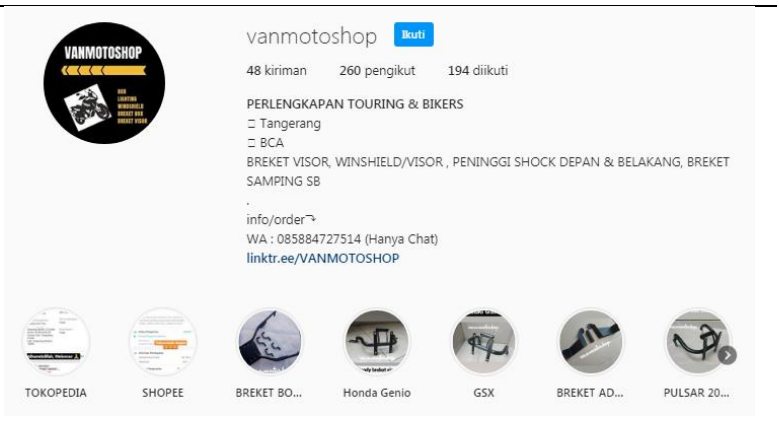

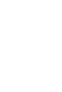




\section{JURNAL MEDIA INFORMATIKA BUDIDARMA}

Volume 4, Nomor 3, Juli 2020, Page 785-796

ISSN 2614-5278 (media cetak), ISSN 2548-8368 (media online)

Available Online at https://ejurnal.stmik-budidarma.ac.id/index.php/mib

DOI 10.30865/mib.v4i3.2242

[4] W. L. Prathama, Frengky dan Sahetapy, "Pengaruh Kemudahan Penggunaan Aplikasi Dan Kepercayaan Konsumen Terhadap Minat Beli Ulang Konsumen E-Commerce Lazada,” Agora, vol. 7, no. 1, 2019.

[5] R. Rahmidani, "Penggunaan E-Commerce Dalam Bisnis Sebagai Sumber Keunggulan Bersaing Perusahaan," in Seminar Nasional Ekonomi Manajemen dan Akuntansi (SNEMA), Padang: Fakultas Ekonomi Universitas Negeri Padang, 2015.

[6] A. A. F. Solihin, H. H. dan Nusa, "Rancang Bangun Sistem Informasi Penjualan, Pembelian dan Persediaan Suku Cadang Pada Bengkel Tiga Putra Motor Garut," J. Infotronik, vol. 2, no. 2, pp. 107-115, 2017.

[7] Y. E. Achyani, M. Wahyudi, and L. Yusuf, "Sistem Informasi Penjualan Aksesoris Vespa Berbasis Web Pada Cv . A . S . Hikmat Motor Bekasi,” J. Sist. Inf. Antar Bangsa. ISSN 2098-8711, vol. 4, no. 2, pp. 185-193, 2015, [Online]. Available: http://ejournalab.com/index.php/jsi/article/viewFile/37/.

[8] Y. Arianti and M. Ashari, "Sistem Informasi Penjualan Pada Toko Al-Idan Variasi Motor Kelurahan Karang Baru, Kecamatan Mataram,” J. Manaj. Inform. dan Sist. Inf., vol. 1, no. 1, p. 46, 2018, doi: 10.36595/misi.v1i1.17.

[9] S. Susanto, Felix Andreas dan Mulyani, "Implementasi Search Engine Optimization (SEO) On Page Pada Web UMKM Batik dan Handicraft," Pros. Semin. Nas. Multi Disiplin Ilmu dan Call Pap. UNISBANK, pp. 185-193, 2015.

[10] Y. T. Alamsyah, Muhammad Ilmar, Pramono, Djoko dan Mursityo, "Implementasi Search Engine Optimization (SEO) Pada Situs Rental-mobil-malang.com Menggunakan Metode Off Page SEO,” J. Pengemb. Teknol. Inf. dan Ilmu Komput., vol. 3, no. 9, pp. 8439-8447, 2019.

[11] D. W. Ariani, Pengendalian Kualitas Statistik (Pendekatan Kuantitatif Dalam Manajemen Kualitas. Yogyakarta: Andi Press, 2004.

[12] F. Royan, Bisnis Model Kanvas Distributor. PT. Gramedia, 2005.

[13] B. Praditya, D. A dan Soepeno, "Penggunaan Aplikasi CMS Wordpress Untuk Merancang Website Sebagai Media Promosi pada Maroon Wedding Malang," Akuntansi, Ekon. dan Manaj. Bisnis, vol. 2, no. 1, pp. 3-69, 2014.

[14] K. Hernawati, "Optimalisasi SEO (Search Engine Optimizer) Sebagai Upaya Meningkatkan Unsur Visibility Dalam Webometric," in Seminar Nasional Matematika dan Pendidikan Matematika, 2019.

[15] G. Kotler, Philip dan Amstrong, Dasar-dasar Pemasaran, Jilid Satu. Jakarta: PT. Prenhallindo, 1997. 